\title{
Impact of Iron Deficiency Anemia on Glycated Hemoglobin (HbA1c) Levels in Diabetics with Controlled Plasma Glucose Levels
}

\author{
Lavanya Rajagopal ${ }^{1 *}$, A. Sundaram ${ }^{1}$, Shivashekar ${ }^{1}$ and Balaji Ramraj ${ }^{2}$ \\ ${ }^{1}$ Department of Pathology, SRM Medical College Hospital and Research Centre, Kattankulathur, Chennai India \\ ${ }^{2}$ Department of community medicine, SRM Medical College Hospital and Research Centre, Kattankulathur, Chennai India
}

\section{ABSTRACT}

Background: Glycated hemoglobin $\left(\mathrm{HbA}_{1} \mathrm{C}\right)$ is used as a gold standard for monitoring glycemic control. American Diabetes Association (ADA) has certified $\mathrm{HbA}_{1} \mathrm{C} \geq 6.5 \%$ as a diagnostic criterion for diabetes mellitus (DM). Recent studies suggest that conditions affecting erythrocyte turnover like Iron deficiency anemia (IDA) alters $\mathrm{HbA}_{1} \mathrm{C}$ levels but their results are conflicting. However the effect of IDA on $\mathrm{HbA}_{1} \mathrm{C}$ is rarely reported.

To determine the impact of IDA on $\mathrm{HbA}_{1} \mathrm{C}$ levels among controlled diabetics [Fasting plasma glucose $(\mathrm{FPG})<126 \mathrm{mg} / \mathrm{dl}$ since last 6 months] independent of blood glucose concentration and its variation according to the degree of anemia.

Methods: This cross-sectional study carried out in SRM Medical College Hospital and Research Centre, Chennai includes totally 300 controlled diabetic patients -Type 2 DM (150 with IDA and 150 without IDA). Medical history recorded. HbA1C, complete hemogram and FPG were tested.

Result: The mean $\mathrm{HbA}_{1} \mathrm{C}$ among controlled diabetics with IDA $(7.86 \pm 0.11 \%)$ was significantly higher than those without IDA (5.45 \pm $0.038 \%)(\mathrm{P}<0.05) . \mathrm{HbA}_{1} \mathrm{C}$ results were higher with the reduction of total hemoglobin $(\mathrm{p}<0.05)$

Conclusion: IDA spuriously elevates $\mathrm{HbA}_{1} \mathrm{C}$ levels independent of blood glucose concentration in controlled-diabetics.HbA $\mathrm{C}$ increases significantly as severity of anemia worsens. Thereby this study insists on the utter importance to exclude IDA and to correct it before any diagnostic or therapeutic decision is made based solely on $\mathrm{HbA}_{1} \mathrm{C}$ level.

Keywords: $H b A_{1}$ C, Iron deficiency Anemia, Diabetes

\section{Introduction}

Glycated hemoglobin $\left(\mathrm{HbA}_{1} \mathrm{C}\right)$ is a form of hemoglobin that is measured to estimate the three-month average blood glucose concentration. It is widely used as a gold standard for monitoring glycemic control over the previous three months as this is the life span of red blood cell. $\mathrm{HbA}_{1} \mathrm{C}$ also serves as a predictor of complications of diabetes. Recently American Diabetes Association (ADA) has certified $\mathrm{HbA}_{1} \mathrm{C} \geq 6.5 \%$ as a diagnostic criterion for diabetes mellitus. ${ }^{[1]}$ However $\mathrm{HbA}_{1} \mathrm{C}$ levels can be influenced by a variety of other factors affecting erythrocyte turnover and glucose homeostasis..$^{[2-5]}$ One such condition affecting erythrocyte turnover is anemia. Anemia may be associated with rapid erythrocyte turnover conditions like acute or chronic blood loss, hemolytic anemia, sickle cell anemia, vitamin $\mathrm{B} 12$ deficiency, pregnancy that lower $\mathrm{HbA}_{1} \mathrm{C}$ levels (or) with slower erythrocytes turnover conditions like Iron deficiency anemia (IDA), alcoholism that increases $\mathrm{HbA}_{1} \mathrm{C}$ levels. However some but not all studies suggest that iron depletion is associated with increased glycation of hemoglobin leading to falsely high values of $\mathrm{HbA}_{1} \mathrm{C}$ independent of glycaemia. ${ }^{[6,7]}$ To shed additional light on this, in the present study we aimed to analyze the effect of IDA on $\mathrm{HbA}_{1} \mathrm{C}$ levels in controlled diabetics (fasting plasma glucose levels $\leq 126 \mathrm{mg} / \mathrm{dl}$ since last 6 months).

\section{Materials and Methods}

This is a cross-sectional study carried out in SRM Medical College Hospital and Research Centre, Chennai (February 2016 to September 2016) after obtaining approval from our institutional ethical committee. All diabetic patients (Type 2 DM) from both outpatient and inpatient departments of our hospital were included in the study evaluation.

Totally 300 controlled diabetics whose FPG level is $<126$ $\mathrm{mg} / \mathrm{dl}$ since last 6 months (150 with IDA and 150 without IDA) were included in this study. These two groups were matched for age, sex and plasma glucose levels. Their blood samples were tested for $\mathrm{HbA}_{1} \mathrm{C}$, hemoglobin $(\mathrm{Hb})$, hematocrit (Hct), Mean corpuscular volume(MCV), Mean corpuscular hemoglobin(MCH), Mean corpuscular hemoglobin concentration(MCHC), Peripheral smear, Serum iron, Ferritin and fasting plasma glucose (FPG) levels. Medical history was recorded.

The anemic patients were selected based on their hemoglobin levels $(\mathrm{Hb}<13 \mathrm{gm} \%$ in males and $<12$ 
gm\% in females) based on definition of World Health Organization (WHO). ${ }^{[8]}$ And those with predominantly microcytic red cell indices $(\mathrm{MCV}<76 \mathrm{fl})$, hypochromic red cell indices $(\mathrm{MCH}<27 \mathrm{pg} / \mathrm{cell}$ and $\mathrm{MCHC}<32 \mathrm{~g} / \mathrm{dl})$ and on their peripheral smear (microcytic hypochromic) were considered to have IDA which was confirmed by low serum iron $(<59 \mu \mathrm{g} / \mathrm{dl}$ in males and $<37 \mu \mathrm{g} / \mathrm{dl}$ in females) \& low serum ferritin $(<15 \mathrm{ng} / \mathrm{ml}$ in males and $<9$ $\mathrm{ng} / \mathrm{ml}$ in females).

Subjects having FPG $>126 \mathrm{mg} / \mathrm{dl}$ (or) RPG $>200 \mathrm{mg} /$ $\mathrm{dl}$ (or) 2 hour post prandial plasma glucose $>200 \mathrm{mg} / \mathrm{dl}$ and patients with hypothyroidism, vitamin B12 deficiency, pregnancy and those having abnormal renal function tests (serum urea, creatinine), hemolytic anemia were excluded from the study.

$\mathrm{HbA}_{1} \mathrm{C}$ was measured by HPLC method using Bio-Rad analyzer. $\mathrm{Hb}, \mathrm{MCV}, \mathrm{MCH}, \mathrm{MCHC}$ were estimated by sysmex XT-1800 analyzer. FPG estimated by glucose oxidase/peroxidase method. Serum ferritin (Bio-Rad Quanimune Ferrin IRMA, Bio-Rad lab) \& Serum iron (TPTZ method).

Statistical analysis: The data are presented as mean \pm S.D for continuous variables. A student's t- test was applied for comparison of group means. Pearson's co-efficient of correlation was calculated to determine correlation between two variables. $\mathrm{P}$ value $<0.05$ was considered statistically significant.

\section{Result}

Our study results show that mean $\mathrm{HbA}_{1} \mathrm{C}$ levels in controlled diabetics with IDA patients was $7.86 \pm 0.11 \%$ while that in controlled diabetic patients without IDA was $5.45 \pm 0.03 \%$. The $\mathrm{HbA}_{1} \mathrm{C}$ levels were significantly higher in IDA patients than those without IDA $(\mathrm{p}<0.05)$. We also observed a statistically significant difference $(\mathrm{p}<0.05)$ in mean $\mathrm{Hb}$ levels in controlled diabetics with and without IDA $(10.33 \pm 0.15 \mathrm{gm} / \mathrm{dl}$ and $14.06 \pm 0.10 \mathrm{gm} / \mathrm{dl}$ respectively $)$ These data are presented in [Table-1].

The mean Hct, MCV, MCH, MCHC, serum iron and ferritin levels in controlled diabetics with IDA and without IDA were $34.20 \pm 0.44,72.67 \pm 1.39,25.52 \pm 0.32,30.20$ $\pm 0.209,32.68 \pm 0.71,10.06 \pm 0.79$ and $41.90 \pm 0.32,86.79 \pm$ $0.39,29.39 \pm 0.12,33.11 \pm 0.08,75.26 \pm 0.79,45.19 \pm 1.11$ respectively.

These data show that Hct, $\mathrm{MCV}, \mathrm{MCH}$ and $\mathrm{MCHC}$ levels were lower in controlled diabetic patients with IDA than in those without IDA and the observed difference was statistically significant as shown in [Table-2].

Additionally when patients were classified according to the degree of anemia, 55 presented with mild anemia, 70 presented with moderate anemia and 25 presented with severe anemia. $\mathrm{HbA}_{1} \mathrm{C}$ results were higher with the reduction of total hemoglobin $(\mathrm{p}<0.05)$ [Fig-1].

Additionally we classified study subjects into well controlled (FPG $<100 \mathrm{mg} / \mathrm{dl}$ ) and controlled diabetics (FPG $100-126 \mathrm{mg} / \mathrm{dl}$ ) and compared $\mathrm{HbA}_{1} \mathrm{C}$ levels between anemic and not anemic groups. However $\mathrm{HbA}_{1} \mathrm{C}$ level was found to be negatively correlated with IDA in study subjects and positively correlated in control subjects $(\mathrm{p}<0.05)$ [Table-3].

The baseline characteristics of the study subjects were analyzed. Among 150 controlled diabetics with IDA, 89 were females (59\%) and 61 were males $(41 \%)$ and among those without IDA 92 were females $(61 \%)$ and 58 were males $(39 \%)$ as shown in [Fig-2]. The mean age of the IDA patients was $50.24 \pm 1.55$ and those without IDA was $54.79 \pm 1.38$.

Table 1: comparison of $\mathrm{HbA}_{1} \mathrm{c} \%$ between anemic and not anemic controlled diabetics.

\begin{tabular}{|c|c|c|c|c|}
\hline Parameters & IDA & No anemia & T test & P value \\
\hline $\mathrm{Hb}(\mathrm{g} / \mathrm{dl})$ & $10.33 \pm 0.15$ & $14.06 \pm 0.10$ & -20.276 & 0.0001 \\
\hline $\mathrm{HbA} 1 \mathrm{c} \%$ & $7.86 \pm 0.11$ & $5.45 \pm 0.03$ & 20.842 & 0.0001 \\
\hline
\end{tabular}

Table 2: comparison of red cell indices.

\begin{tabular}{|c|c|c|c|c|}
\hline Parameters & IDA & Not anemic & T test & P value \\
\hline Hct $(\%)$ & $34.20 \pm 0.44$ & $41.90 \pm 0.32$ & -13.922 & 0.0001 \\
\hline $\mathrm{MCV}(\mathrm{fl})$ & $72.67 \pm 1.39$ & $86.79 \pm 0.39$ & -9.718 & 0.0001 \\
\hline $\mathrm{MCH}(\mathrm{pg} / \mathrm{cell})$ & $25.52 \pm 0.32$ & $29.39 \pm 0.12$ & -10.930 & 0.0001 \\
\hline $\mathrm{MCHC}(\mathrm{gm} / \mathrm{dl})$ & $30.20 \pm 0.20$ & $33.11 \pm 0.08$ & -13.358 & 0.0001 \\
\hline
\end{tabular}


Table 3: MEAN HbA 1 C\% GENDERWISE IN WELL CONTROLLED AND CONTROLLED DIABETICS.

\begin{tabular}{|c|c|c|c|c|c|c|}
\hline & Females & & Males & & Total & \\
\hline & IDA $(n=89)$ & NA $(n=58)$ & IDA $(n=61)$ & NA $(n=92)$ & IDA $(n=150)$ & $N A(n=150)$ \\
\hline $\mathrm{HbA}_{1} \mathrm{C}$ in $\mathrm{FPG}<100$ & $7.88 \pm 0.17$ & $5.45 \pm 0.06$ & $7.62 \pm 0.25$ & $5.33 \pm 0.06$ & $7.77 \pm 0.15$ & $5.38 \pm 0.04$ \\
\hline $\mathrm{HbA}_{1} \mathrm{C}$ in FPG $100-126$ & $7.93 \pm 0.22$ & $5.78 \pm 0.04$ & $7.95 \pm 0.22$ & $5.47 \pm 0.06$ & $7.94 \pm 0.16$ & $5.57 \pm 0.05$ \\
\hline T test & -0.183 & -3.560 & -0.983 & -1.568 & -0.775 & -2.749 \\
\hline$P$ value & 0.855 & 0.001 & 0.330 & 0.120 & 0.439 & 0.007 \\
\hline
\end{tabular}

Fig. 1: HbA1c VARIATION WITH DEGREE OF ANEMI.

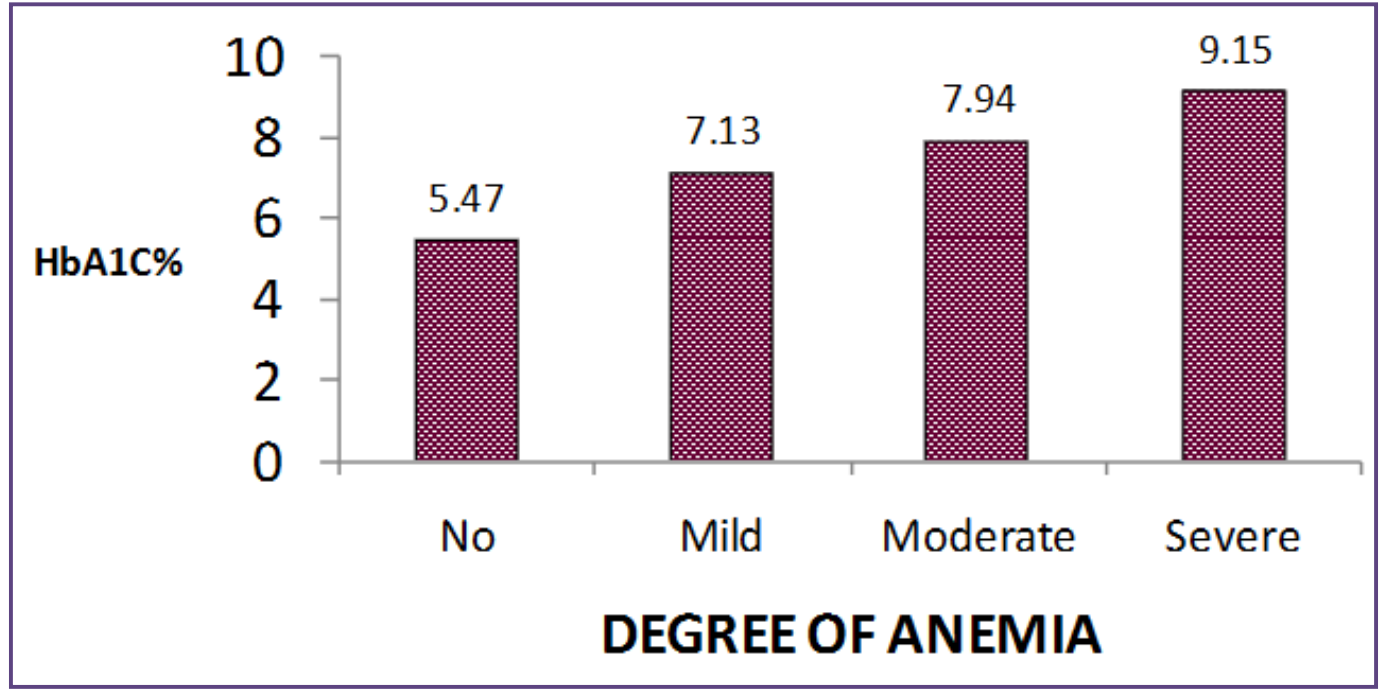

ANOVA - 202.613, P - 0.0001

No anemia to mild anemia, T test $\quad-\quad-7.591, \mathrm{P}-0.0001$

Mild anemia to Moderate anemia, T test - $-3.306, \mathrm{P}-0.001$

Moderate anemia to Severe anemia, T test - $\quad-5.805, \mathrm{P}-0.0001$

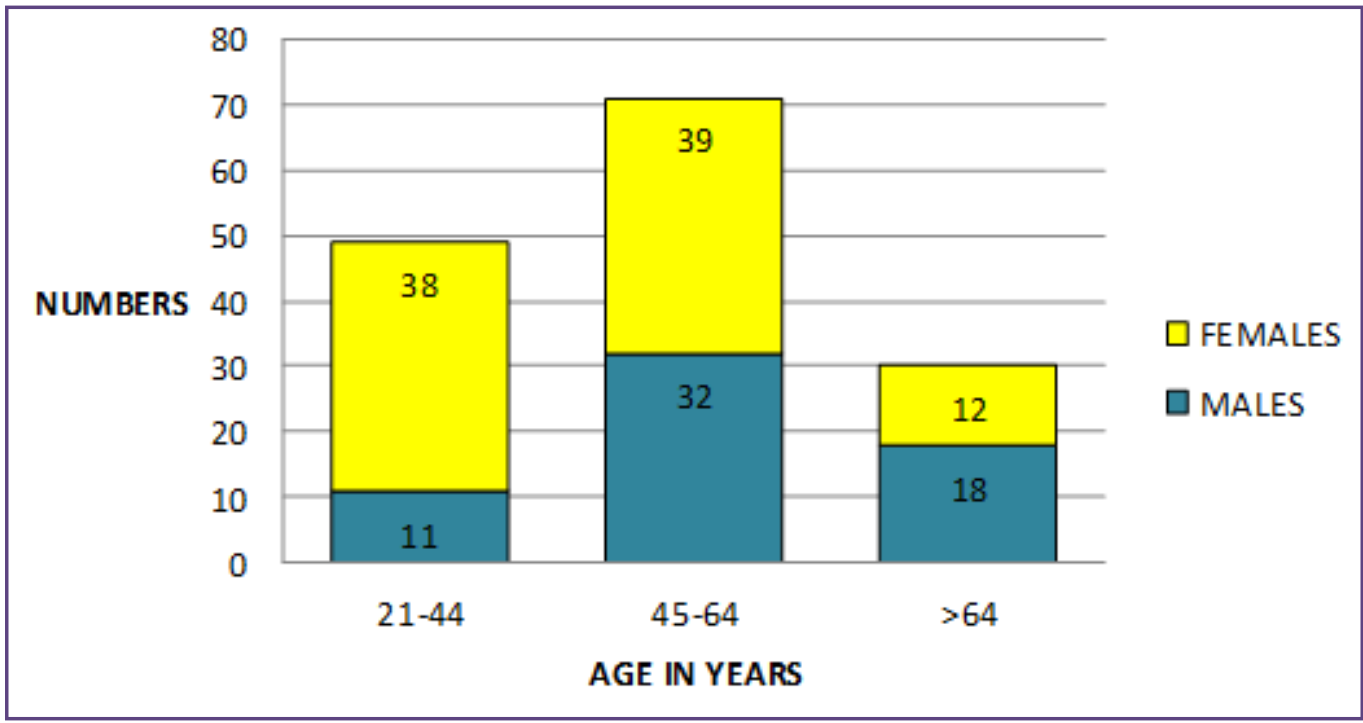

Fig. 2: AGE AND SEX DISTRIBUTION OF ANEMIA IN DIABETICS. 


\section{Discussion}

Diabetes mellitus is a group of metabolic diseases characterized by hyperglycemia and its incidence is sharply increasing worldwide with many long term macrovascular and microvascular complications. ${ }^{[9]}$ The $\mathrm{HbA}_{1} \mathrm{C}$ test is commonly used to diagnose diabetes and also as a marker of glycemic status over previous 3 months. Many studies suggest that anemia is twice common in diabetics when compared with non-diabetics. ${ }^{[10-12]}$ Prevalence of anemia is estimated about $10-30 \%$ in patients with diabetes. ${ }^{[13]}$ The etiology of anemia in diabetics is multi- factorial and includes inflammation, nutritional deficiency, concomitant autoimmune diseases, drugs, hormonal changes in addition to kidney disease. Approximately one-third of patients with anemia exhibit iron deficiency ${ }^{[14]}$ Though there are several studies on the role of anemia on $\mathrm{HbA}_{1} \mathrm{C}$ levels, only few studies have reported on the effect of iron deficiency anemia on $\mathrm{HbA}_{1} \mathrm{C}$ levels.

Our study result suggested that IDA elevates $\mathrm{HbA}_{1} \mathrm{C}$ levels independent of plasma glucose concentration. This is in accordance with the study results of Brooks et al, Gram-Hansen et al and Coban et al who showed that iron therapy significantly reduces $\mathrm{HbA}_{1} \mathrm{C}$ levels in non-diabetic population. ${ }^{[6,7]}$ Also our results positively correlates with results of Koga et al, Shanti et al who showed that $\mathrm{HbA}_{1} \mathrm{C}$ levels in patients with iron deficiency anemia (IDA) were higher than those of subjects with normal iron levels. ${ }^{[15,16]}$ Our finding confirms the study results of Tarim et al, who reported that iron deficiency elevate HbA1C levels in diabetics when compared with iron-sufficient controls when matched for FPG levels. ${ }^{[1]}$

This elevation of $\mathrm{HbA}_{1} \mathrm{C}$ in IDA may be explained by iron deficiency related changes in the quaternary structure of hemoglobin molecule increasing the glycation of globin chain. ${ }^{[6]}$ Some studies proposed that the glycation of hemoglobin is a permanent process and hence the $\mathrm{HbA}_{1} \mathrm{C}$ levels in red blood cell will increase as the cell's age increases. They also found that after treatment of IDA in patients with normal blood glucose levels, $\mathrm{HbA}_{1} \mathrm{C}$ concentration was reduced because of very young red cells. However if iron deficiency persists for a long time, production of red cells would fall, leading to a higher average age of circulating erythrocytes and therefore increased $\mathrm{HbA}_{1} \mathrm{C}$ levels. ${ }^{[16]}$

However our study results differs with study results of E.S.Ford et al, Van Heyningen et al and Saudek et al who reported that there is no significant difference in mean $\mathrm{HbA}_{1} \mathrm{C}$ concentration according to IDA status. ${ }^{[6,17,18]}$
Few studies by Horton BF \& Huisman TH, Rau et al and Sinha et al reported that $\mathrm{HbA}_{1} \mathrm{C}$ level decrease in IDA patients and this contradicts with our study result. ${ }^{[6,19]}$

There are several strengths of this study. First we designed this study to reduce as much as possible confounding factors that could affect our $\mathrm{HbA}_{1} \mathrm{C}$ results like renal insufficiency, pregnancy, alcohol etc. Second we also analyzed $\mathrm{HbA}_{1} \mathrm{C}$ results in different degrees of anemia (mild, moderate and severe) and observed that $\mathrm{HbA}_{1} \mathrm{C}$ level increases as severity of anemia worsens.

Limitations to this study were we couldn't follow up patients after iron supplementation which might have given a new dimension to our study and since this was a cross-sectional study and the mechanism by which anemia affects $\mathrm{HbA1c}$ was not evaluated.

\section{Conclusion}

IDA spuriously elevates $\mathrm{HbA}_{1} \mathrm{C}$ levels independent of plasma glucose concentration. $\mathrm{HbA}_{1} \mathrm{C}$ level increases significantly with severity of anemia. Thereby this study insists on the utter importance to exclude IDA in diabetes and to correct it before any diagnostic or therapeutic decision is made based solely on $\mathrm{HbA}_{1} \mathrm{C}$ level.

\section{Acknowledgements}

I would like to thank our Dean Dr. A.Sundaram, SRM Medical College Hospital and Research Center for his support throughout the study. Am thankful to all the participating people for their cooperation.

\section{Reference}

1. Christy AL, Manjrekar PA, Babu RP, Hegde A. Influence of Iron Deficiency Anemia on Hemoglobin A1C Levels in Diabetic Individuals with Controlled Plasma Glucose Levels. Iran Biomed J. 2014;18(2):88.

2. Wolffenbuttel BH, Herman WH, Gross JL, Dharma lingam M, Jiang HH, Hardin DS. Ethnic differences in glycemic markers in patients with type 2 diabetes. Diab care. 2013;36:2931-6.

3. Herman WH, Ma Y, Uwaifo G, Haffner S, Kahn SE, Horton ES, et al. Differences in A1C by race and ethnicity among patients with impaired glucose tolerance in the Diabetes Prevention Program. Diab care. 2007;30:2453-7.

4. Nathan DM, International Expert Committee. International Expert Committee report on the role of the $\mathrm{A} 1 \mathrm{C}$ assay in the diagnosis of diabetes. Diab Care. 2009;32:e160.

5. Soulimane S, Simon D, Herman WH, Lange C, Lee CM, Colagiuri S,et al. HbAlc, fasting and $2 \mathrm{~h}$ plasma glucose in current, ex-and never-smokers: a meta-analysis. Diabetologia. 2014;57:30-9.

6. Kalasker V, Kodliwadmath MV, Bhat H. Effect of iron deficiency anemia on glycosylated hemoglobin levels in nondiabetic Indian adults. Int J Med Hlth Sci. 2014;3(1):40-3. 
7. Coban E, Ozdogan M, Timuragaoglu A. Effect of iron deficiency anemia on the levels of hemoglobin A1C in nondiabetic patients. Acta Haematol. 2004;112(3):126-8.

8. World Health Organization, Worldwide prevalence of anaemia 1993-2005. WHO global database on anaemia, WHO, 2008

9. Kilpatrick ES, Bloomgarden ZT, Zimmet PZ. Is haemoglobin A1c a step forward for diagnosing diabetes. BMJ. 2009;339:b4432.

10. Thomas MC, MacIsaac RJ, Tsalamandris C, Power D, Jerums G. Unrecognized Anemia in Patients With Diabetes A cross-sectional survey. Diab care. 2003;26(4):1164-9.

11. Cawood TJ, Buckley U, Murray A, Corbett M, Dillon D, Goodwin B, et al. Prevalence of anaemia in patients with diabetes mellitus. Irish J Med Sci. 2006;175(2):25-7.

12. Stevens PE, O'Donoghue DJ, Lameire NR. Anaemia in patients with diabetes: unrecognised, undetected and untreated? Current medical research and opinion. 2003;19(5):395-401.

13. Hosseini MS, Rostami Z, Saadat A, Saadatmand SM, Naeimi E. Anemia and microvascular complications in patients with type 2 diabetes mellitus. Nephro-urol. 2014;6(4).
14. Wu AC, Lesperance L, Bernstein H. Screening for iron deficiency. Pediatrics in Review. 2002;23(5):171-8.

15. Koga M, Saito H, Mukai M, Matsumoto S, Kasayama S. Influence of iron metabolism indices on glycated haemoglobin but not glycated albumin levels in premenopausal women. Acta diabetologica. 2010;47(1):65-9.

16. Shanthi B, Revathy C, Manjula Devi AJ, et al. Effect of iron deficiency on glycation of haemoglobin in nondiabetics. J Clin Diagn Res. 2013;7(1):15-17.

17. Ford ES, Cowie CC, Li C, Handelsman Y, Bloomgarden ZT. Iron-deficiency anemia, non-iron deficiency anemia and $\mathrm{HbA} 1 \mathrm{c}$ among adults in the US. J Diabetes. 2011;3(1):67-73.

18. Saudek CD, Herman WH, Sacks DB, Bergenstal RM, Edelman D, Davidson MB. A new look at screening and diagnosing diabetes mellitus. J Clin Endocrinol Metab. 2008;93(7):2447-53.

19. Sinha N, Mishra TK, Singh T, Gupta N. Effect of iron deficiency anemia on hemoglobin A1c levels. Ann Lab Med. 2012;32(1):17-22.

*Corresponding author:

Dr. R. Lavanya Rajagopal M.D., 902, B-block, SRM Medical Staff Quarters, SRM Medical College Hospital and Research Centre, Kattankulathur, Chennai , Tamilnadu, India .603203

Email: drrlavan@yahoo.co.in

Date of Submission : 26.10.2016

Date of Acceptance : 10.01.2017

Financial or other Competing Interests: None.

Date of Publication : 07.04.2017 